\title{
Impact of mixing treated industrial water with olive mill wastewater on vetch (Vicia sativa L.) germination and early seedling growth
}

\author{
Naji K. Al-Mefleh ${ }^{1 *}$, Maher J. Tadros ${ }^{1}$, Jalal A. Al-tabbal ${ }^{2}$ \\ ${ }^{1}$ Department of Natural Resources, Jordan University of Science and Technology, P.O. Box 3030, Irbid, Jordan \\ ${ }^{2}$ Department of Nutrition and Food Processing, Al-Huson University College, Al-Balqa Applied University, Irbid, Jordan
}

*Corresponding author: nmefleh@just.edu.jo

\begin{abstract}
Vetch is a forage crop that is widely grown in high rainfall areas in Jordan for forage production and grazing. Growing vetch species out of the season will need irrigation, which is very expensive. In here, we propose application of wastewater or olive mill wastewater as alternative to the fresh water. An experiment was carried out to evaluate the effect of diluting the industrial water (IND) with olive mill wastewater (OMWW) on the vetch germination (GR) and early seedling growth under controlled conditions. The water treatments consisted of T1 (pure $\left.\mathrm{IND}_{100 \%}\right)$, T2 (mix of $\left.\mathrm{IND}_{75 \%}+\mathrm{OMWW}_{25 \%}\right)$, T3 $\left(\mathrm{IND}_{50 \%}+\mathrm{OMWW}_{50 \%}\right)$, T4 $\left(\mathrm{IND}_{25 \%}+\mathrm{OMWW}_{75 \%}\right)$ and T5 $($ pure $\mathrm{OMWW}_{100 \%}$ ) and tap water (control). This experiment was designed in a CRD with three replications for each treatment. Several measurements on the morphological and biochemical analysis were taken during this study such as seed germination (GR), as well as the seedlings fresh weight of shoot (FWS), dry weight of shoot (DWS), fresh weight of shoot (FWR), dry weight of root (DWR), shoot length (SL), root length (RL) and the ratios of DWS/DWR and SL/RL. The water treatments had a significant influence on data taken, in which the highest mean values of morphological characteristics were obtained under the T1, while the lowest were obtained under the T5 due to high phenols concentrations. The OMWW treatment showed an adverse effect on GR, DWS, DWR, SL, and RL due to low pH values (4.5) and high phenols concentration (1700 mg/L). In contrast, the industrial water showed low to moderate effect on the vetch seed germination. The means of DWS and DWR under T3 and T4 were not significantly different from each other but were different comparing with control. It is recommended that the use of a mixture of OMWW and the Industrial water will have a positive effect on Vetch growth.
\end{abstract}

Keywords: blue water; seed germination; wastewater dilution; water quality.

Introduction

The agro-industrial activity of olive oil production is one of the most important agri-based activity in many countries of the Mediterranean Region. This industry is estimated to generate revenues of around 100 million JOD, as stated by the Amman Chamber of Commerce (DOS, 2016) and supports the livelihood of approximately 180,000 families in Jordan. The olive oil production industry is associated with the generation of the large quantities of by-products, such as wastewater (olive mill wastewater - OMWW). Management, treatment, and safe disposal of OMWW raise serious environmental concerns especially that the olive mills are considered as family-run businesses and olive mills are located in the olive production area, which makes individual on-site treatment unfeasible. In general, it is estimated that the amount of wastewater produced ranges from 1.0-1.2 $\mathrm{m}^{3}$ per ton of product depending on the type of production process (Azbar, 2009). Jordan is the $8^{\text {th }}$ among top ten producers of the olive oil production in the world with the production of approximately 26,000 ton of olive oil for the production season of 2015-2016 (JOPEA, 2016). Currently, the only method available for the disposal of OMWW in Jordan is transporting the OMWW without any treatment from the mill to the landfill designed for receiving the effluent (MWI, 2013). The untreated OMWW has the number of characteristics, which include dark color, specific smell, acidic $\mathrm{pH}$, and high organic content (Ayouba, 2014). The organic content consists mainly of classes of pollutants such as polyphenols known to exhibit antimicrobial, eco-toxic and phytotoxic properties (Paraskeva, 2007). Discharge of olive waste into soil may cause a number of environmental issues, such as leaf and fruit abscission (Erel, 2008) and inhibition of seed germination, enhancement of microbial fermentation with the production of methane (Azbar, 2004) and proliferation of the phosphorous content (Segal, 2011).

The recent study carried out by Rusan et al. (2015) evaluated the impact of treated and untreated OMWW on seed germination of barley (Hordeum vulgare L.). This study showed 
that $100 \%, 75 \%$ and $50 \%$ OMWW displayed phytotoxic properties and completely prohibited seed germination. However, 25\% OMWW dilution showed some enhancement in Germination Rate Index (GRI), which proves that the treated or diluted OMWW could be used for irrigation. Komilis (2005) studied the effect of OMWW on seed germination after various pretreatment techniques. The results of the study showed that phytotoxicity of OMWW was decreased with increased dilution with water, after aeration of OMW and without $\mathrm{pH}$ adjustment. The unprocessed OMWW cause modification on physicochemical features of soils, in which the phenolic compounds were detected at a depth of $1.2 \mathrm{~m}$ four months after the application of OMWW (Mekki, 2006). Zenjari (2001) found that spreading of OMWW on soils resulted in the increase of organic carbon, Kjeldahl $\mathrm{N}$, total phosphorus, potassium in addition to the increase of electrical conductivity, phenol concentration and salinization level in soils which could negatively impact soil fertility. In general, the irrigation by the reclaimed wastewater demonstrates a positive impact on the plant growth due to the increased water availability and soil fertility (Palese, 2009). On the other hand, accumulation of salt in the root area shows a negative effect on the plant (Biggs, 2009) and potentially can be a source of groundwater contamination due to leaching below the root zone (Aragues, 2004).

Mekki (2007) studied effects of treated and untreated OMWW on seed germination, plant growth, and soil fertility and showed beneficial effects of using treated olive mill wastewater in irrigation of different crops. Tomato (Lycopersicone sculentum), chickpea (Cicer arietinum), fava bean (Viciafaba), wheat (Triticum durum), and barley (Hordeum vulgare) were tested for germination index and growth. In general, the plants irrigated with treated wastewater showed an improvement in seed biomass, spike number, plant growth, and improved dry productivity compared to plants irrigated by normal water. Also, an increase in the germination index from 110 to $115 \%$ was observed. The study has concluded that treated OMWW can be used for ferti-irrigation of the crops. However, diluted untreated OMW causes leaf necrosis and low productivity.

In Jordan, the possibility of using treated OMWW in irrigation of some types of crops is considered significant for agriculture since Jordan is recognized as the $4^{\text {th }}$ poorest country in the world in terms of the water resources (USAID, 2012). Therefore, the re-use of the large amounts of OMWW generated during the olive-pressing season could potentially reduce the use of potable quality water in agriculture (Chartzoulakis, 2005).

Vicia sativa $L$. is a vine annual forage legumes crop belonging to Fabaceae family known as common vetch, native to the Mediterranean and southern Europe growing in spring. It has rapid growth and characterized by rapid re-growth after harvesting. Vetch stem is weak, leaves compound consist of several leaflets, purple flowers and seeds are black and round (The Forage Information System, 2009).

In Jordan, common vetch is known as Beekia and is grow for decades. It is a known crop for the local community as highly nutritive valued and seed production (Reeve, 1990). Vetch is being useful for grazing, hay production, for forage crop mixture, green manuring, fix nitrogen and can be used in cropping rotations to disrupt the life cycle of cereal root pathogens (Reeve, 1990; Saoub et al., 2012).

The main goal of this research paper is to study the impacts of industrial water and olive wastewater on germination of vetch seeds under controlled conditions with different dilution treatments. In this study we investigated the possibility of using OMWW on vetch cultivation as it is produced in huge quantities in Jordan. This was tested as another alternative resource of irrigation water. The vetch was selected since it is used as well-known forage source and a nitrogen-fixer. As a result of this research, the main outcomes will contribute to the preservation of precious drinking water resources by using the treated wastewater for irrigation of non-edible vegetation.

\section{Results and Discussion}

\section{Water quality characteristics}

The water quality showed that the dilution percentage of industrial water (IND) in olive mill wastewater (OMWW) increases as the $\mathrm{pH}$ increases, which leads to decrease the soil acidity (Table 1 ). In the mix and dilution of water treatments, the minimum $\mathrm{pH}$ value was 4.6 at $\mathrm{OMWW}_{100 \%}$ and the maximum was 8.8 at $\mathrm{IND}_{75} \%+\mathrm{OMWW}_{25} \%$. While, the EC was the highest $(8.4 \mathrm{dS} / \mathrm{m})$ for $\mathrm{OMWW}_{100} \%$ and the lowest $(3.9$ $\mathrm{dS} / \mathrm{m}$ ) for $\mathrm{IND}_{100 \%}$. However, other water quality parameters such as EC, $\mathrm{Na}, \mathrm{K}, \mathrm{TSS}, \mathrm{PO} 4, \mathrm{COD}, \mathrm{POD}$, turbidity, and phenols were decreased as the percentage of IND water increased in the mix with OMWW. The water quality concentrations of $\mathrm{Ca}$, $\mathrm{Mg}$, and NO3 were increased as the percentage of IND water increased. The OMWW has higher concentration of $\mathrm{K}, \mathrm{Ca}$, oil grease, TSS, PO4, POD, COD, phenols and lower concentration of $\mathrm{Na}$ and $\mathrm{NO} 3$ compared to industrial water. The results of the OMWW analysis in general are similar to the results reported by Ayouba (2014) and Rusan (2015). Similarly, Zenjari (2001) showed that OMWW increase the organic carbon, N, P, K as well as increase the EC and phenolic compounds.

\section{Seed germination of vetch under different mixture of water qualities}

The main concern in using of OMWW in irrigation is the availability of phenolic acids. The phenols has an impact on the seed germinations, crop growth, and soil properties as explained by Mekki (2007). One solution is to enhance the quality of OMWW by treating physically, chemically, or by diluting with other types water qualities. This study found that mixing IND with OMWW has a significant effect on the germination percentage of vetch seeds. The results of germination characteristics of vetch in response to mixing IND with OMWW with different percentages showed that the germination percentage were not significantly different between $I \mathrm{ND}_{100 \%}$ andIND ${ }_{75 \%}+\mathrm{OMWW}_{25 \%}$ but they were different from that at $I \mathrm{ND}_{50 \%}+\mathrm{OMWW}_{50 \%}, \mathrm{IND}_{25 \%}+\mathrm{OMWW}_{75 \%}$, and $\mathrm{OMWW}_{100 \%}$ (Fig 1). A trend of similar results was reported by Mesad (2014) and Tadros et al. (2012) showing that germination was increased with treated OMWW. Compared to seeds germinated under Tap water (98.72\%), the decrease in 
germination percentage was $8.83 \%, 11.67 \%, 40.44 \%, 45.06 \%$, $62.00 \%$ at $I N D_{100 \%}, I N D_{75 \%}+\mathrm{OMWW}_{25 \%}, \mathrm{IND}_{50 \%}+\mathrm{OMWW}_{50 \%}$, $\mathrm{IND}_{25 \%}+\mathrm{OMWW}_{75 \%}$, OMWW $100 \%$, respectively. Our results showed that the diluting INDW + OMWW delay but did not constrain the seed germination similar to results obtained by Krogmeier and Bremner (1989). The increase in the percentage of OMWW affect germination percentage. The results of this study showed that using the OMWW is adversely affect the crop production due to toxicity of high phenols concentration. Mas'ad (2014) showed that decreasing the phenolic compounds as results of treated OMWW cause positive effect on vetch. In contrast, the industrial water showed light to moderate effect on the crop growth or in seed germination as well as the seedling growth (Al-tabbal and Amamry, 2014).

\section{Effect of mixing water qualities on the fresh weight shoot and root of vetch germination}

The fresh shoot and root weight was investigated in the seed germination (Fig 2). The effect of mixing of industrial water and olive mill wastewater had a significant effect on the fresh weight of root and shoot. The IND $100 \%$ scored the highest shoot fresh weight per plant $(138.91 \mathrm{gm})$ and the lowest $(57.44 \mathrm{gm})$ under $\mathrm{OMWW}_{100 \%}$. The nutrient solution in the IND water is rich with nutrients compared to the other treatments, which positively affected the growth and fresh weight of shoot as well. In shoot, from physiological view, the cell content is increased with nutrients causing an increase in solute of the cells and then increase the movement of water toward the cell based on the gradient. The mean of the shoot fresh weight per plant under $\mathrm{IND}_{50 \%}+\mathrm{OMWW}_{50 \%}$ was not different from $\mathrm{IND}_{50 \%}+$ $\mathrm{OMWW}_{25 \%}$ and from $\mathrm{IND}_{25 \%}+\mathrm{OMWW}_{75 \%}$, but they were different from the mean at $\mathrm{OMWW}_{100 \%}$. With respect to the fresh weight shoot (169 gm) under the tap water, the decrease percentage of fresh weight shoot was $14.20 \%, 30.86 \%, 41.36 \%$, $45.69 \%, 64.82 \%$ at $I \mathrm{ND}_{100 \%}, \mathrm{IND}_{75 \%}+\mathrm{OMWW}_{25 \%}, \mathrm{IND}_{50 \%}+$ $\mathrm{OMWW}_{50 \%}, \mathrm{IND}_{25 \%}+\mathrm{OMWW}_{75 \%}, \mathrm{OMWW}_{100 \%}$, respectively. While, the fresh weight of roots was $4.85 \%, 17.48 \%, 29.13 \%$, $32.04 \%, 53.40 \%$ at $\mathrm{IND}_{100 \%}, \mathrm{IND}_{75 \%}+\mathrm{OMWW}_{25 \%}, \mathrm{IND}_{50 \%}+$ $\mathrm{OMWW}_{50 \%}, \mathrm{IND}_{25 \%}+\mathrm{OMWW}_{75 \%}, \mathrm{OMWW}_{100 \%}$, respectively. The means of the fresh root weight at $\mathrm{IND}_{50 \%}+\mathrm{OMWW}_{50 \%}$, $\mathrm{IND}_{25 \%}+\mathrm{OMWW}_{75 \%}$ were not different from each other, but they were different from those means at IND $_{100 \%}$ and $\mathrm{OMWW}_{100 \%}$

\section{Effect of mixing water on vetch germination and dry weight of shoot and root}

The results of mixing of industrial water with olive mill wastewater at different ratios showed a significant effect in seed vetch morphological parameters of dry weight shoot and dry weight root in the early growth stages (Fig 3). Significant differences $(p<0.05)$ indicated that the mixing ratio of $I_{N D_{100 \%}}$ scored the highest dry weight shoot per plant (12.54 gm) fallowed by $9.96,8.11,7.30,4.60 \mathrm{gm}$ under water treatments of $\mathrm{IND}_{75 \%}+\mathrm{OMWW}_{25 \%}, \mathrm{IND}_{50 \%}+\mathrm{OMWW}_{50 \%}, \mathrm{IND}_{25 \%}+$
$\mathrm{OMWW}_{75 \%}, \mathrm{OMWW}_{100 \%}$, respectively. The means of dry weight shoot per plant under $I \mathrm{ND}_{50 \%}+\mathrm{OMWW}_{50 \%}, \mathrm{IND}_{25 \%}+$ $\mathrm{OMWW}_{75} \%$ were not different from each other but they were different from other treatments. With respect to the shoot dry weight (15.42 gm) using tap water, the decrease percentage of shoot dry weight was $18.68 \%, 35.41 \%, 47.41 \%, 52.59 \%$, $70.23 \%$ under treatments of $\mathrm{IND}_{100 \%}, \mathrm{IND}_{75 \%}+\mathrm{OMWW}_{25 \%}$, $\mathrm{IND}_{50 \%}+\mathrm{OMWW}_{50 \%}, \mathrm{IND}_{25 \%}+\mathrm{OMWW}_{75 \%}, \mathrm{OMWW}_{100 \%}$, respectively. Root dry weight was significantly different under all the treatments of mixing the industrial water with olive mill wastewater. The highest $(7.11 \mathrm{gm})$ root weight was observed under $\mathrm{IND}_{100 \%}$ and the lowest $(3.13 \mathrm{gm})$ under $\mathrm{OMWW}_{100 \%}$. Compared to the root dry weight $(8.02 \mathrm{gm})$ at tap water, the rate of decrease was $11.24 \%, 25.09 \%, 40.82 \%, 44.69 \%$, $60.92 \%$, respectively, at $I \mathrm{IND}_{100 \%}, \mathrm{IND}_{75 \%}+\mathrm{OMWW}_{25 \%}, \mathrm{IND}_{50 \%}+$ $\mathrm{OMWW}_{50 \%}, \mathrm{IND}_{25 \%}+\mathrm{OMWW}_{75 \%}, \mathrm{OMWW}_{100 \%}$. Mixing OMWW with IND may reduce the effect of phenolic compounds and nutrients. Also, Mekki et al (2007) showed that the diluted OMWW with tap water caused low productivity and leaf necrosis.

\section{Effect of mixing water qualities on plant height and root length of vetch germination}

Mixing industrial water and olive mill wastewater with different percentages showed a significant effect on vetch morphological parameters of plant such as height and root length (Fig 4). Our results are in agreement with Mekki (2007) findings. The plant height was the highest $(5.50 \mathrm{~cm})$ at $I^{N N D_{100 \%}}$ and the lowest $(2.93 \mathrm{~cm})$ at $\mathrm{OMWW}_{100 \%}$. The means of the pant height between any two sequences treatments were not significant from each other. The decrease percentage of plant height was $11.42 \%, 15.92 \%, 21.45 \%, 32.18 \%, 39.10 \%$, respectively, at $\mathrm{IND}_{100 \%}, \mathrm{IND}_{75 \%}+\mathrm{OMWW}_{25 \%}, \mathrm{IND}_{50 \%}+$ $\mathrm{OMWW}_{50 \%}, \mathrm{IND}_{25 \%}+\mathrm{OMWW}_{75 \%}, \mathrm{OMWW}_{100 \%}$, compared with the plant height $(6.42 \mathrm{~cm})$ at tap water. For the root length, we observed 14.49\%, 22.59\%, 33.02\%, 45.33\%, 54.36\%, respectively, at $\mathrm{IND}_{100 \%}, \mathrm{IND}_{75 \%}+\mathrm{OMWW}_{25 \%}, \mathrm{IND}_{50 \%}+$ $\mathrm{OMWW}_{50 \%}, \mathrm{IND}_{25 \%}+\mathrm{OMWW}_{75 \%}, \mathrm{OMWW}_{100 \%}$, compared with the root length $(1.76 \mathrm{~cm})$ at tap water. However, decreasing the ratio of mixing OMWW/IND can be used for irrigation and it can enhance the germination index and vice versa. Rusan et al. (2015) showed that $100 \%, 75 \%$ and $50 \%$ of OMWW displayed phytotoxic properties and completely prohibited seed germination. The phytotoxicity of OMWW was decreased with increased dilution with water, after aeration of OMW and without pH adjustment (Komilis, 2005).

\section{Effect of mixing water qualities on dry weight of shoot/root ratio and root/shoot length ratio}

Mixing the industrial water and olive mill wastewater with different percentages had a significant effect on dry weight of shoot/root ratio (SDW/RDW) (Fig 5). However, it had a significant effect on the shoot/root length ratio (SL/RL). The mean of the highest dry shoot weight to dry root weight 
Table 1. Water quality analysis for the different mixing percentage of water types was conducted in the laboratories of Jordan University of Science and Technology (JUST).

\begin{tabular}{|c|c|c|c|c|c|c|}
\hline Parameters & $\begin{array}{l}\text { Tap } \\
\text { water }\end{array}$ & $\mathrm{OMWW}_{100 \%}$ & \multicolumn{3}{|c|}{ Treatments } & $\mathrm{IND}_{75 \%}+\mathrm{OMWW}_{25 \%}$ \\
\hline $\mathrm{pH}$ & 7.9 & 4.6 & 9.2 & 6.1 & 7.6 & 8.8 \\
\hline $\mathrm{Na}(\mathrm{mg} / \mathrm{L})$ & 225 & 124 & 330 & 140 & 155 & 170 \\
\hline $\mathrm{K}(\mathrm{mg} / \mathrm{L})$ & 78 & 2500 & 45 & 1885 & 1240 & 640 \\
\hline $\mathrm{Ca}(\mathrm{mg} / \mathrm{L})$ & 390 & 200 & 120 & 230 & 265 & 290 \\
\hline TSS (mg/L) & 14 & 3100 & 370 & 2420 & 1735 & 980 \\
\hline NO3 (mg/L) & 45 & 11 & 39 & 18 & 25 & 32 \\
\hline PO4 (mg/L) & 30 & 65 & 16 & 54 & 40 & 28 \\
\hline $\mathrm{BOD}(\mathrm{mg} / \mathrm{L})$ & 200 & 40000 & 496 & 30125 & 20248 & 10370 \\
\hline $\mathrm{COD}(\mathrm{mg} / \mathrm{L})$ & 490 & 53000 & 960 & 39990 & 26980 & 13970 \\
\hline
\end{tabular}

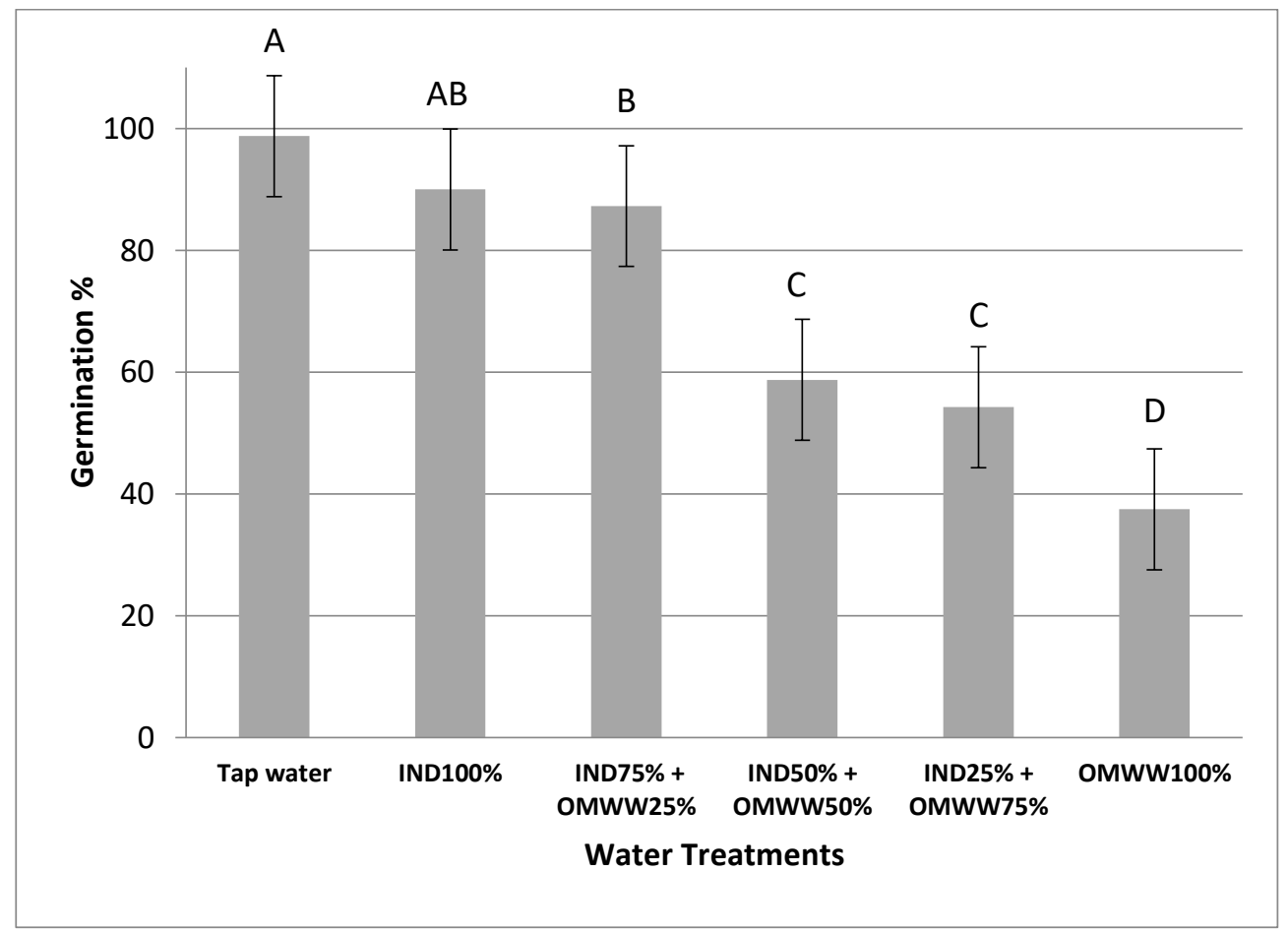

Fig 1. Germination characteristics of vetch (Vicia sativa) in response to different wastewater under controlled environment conditions. Values with the same letters are not significantly different based on least significant difference (LSD $=11.03 \%$ for the seed germination, $P=0.05$ ). 


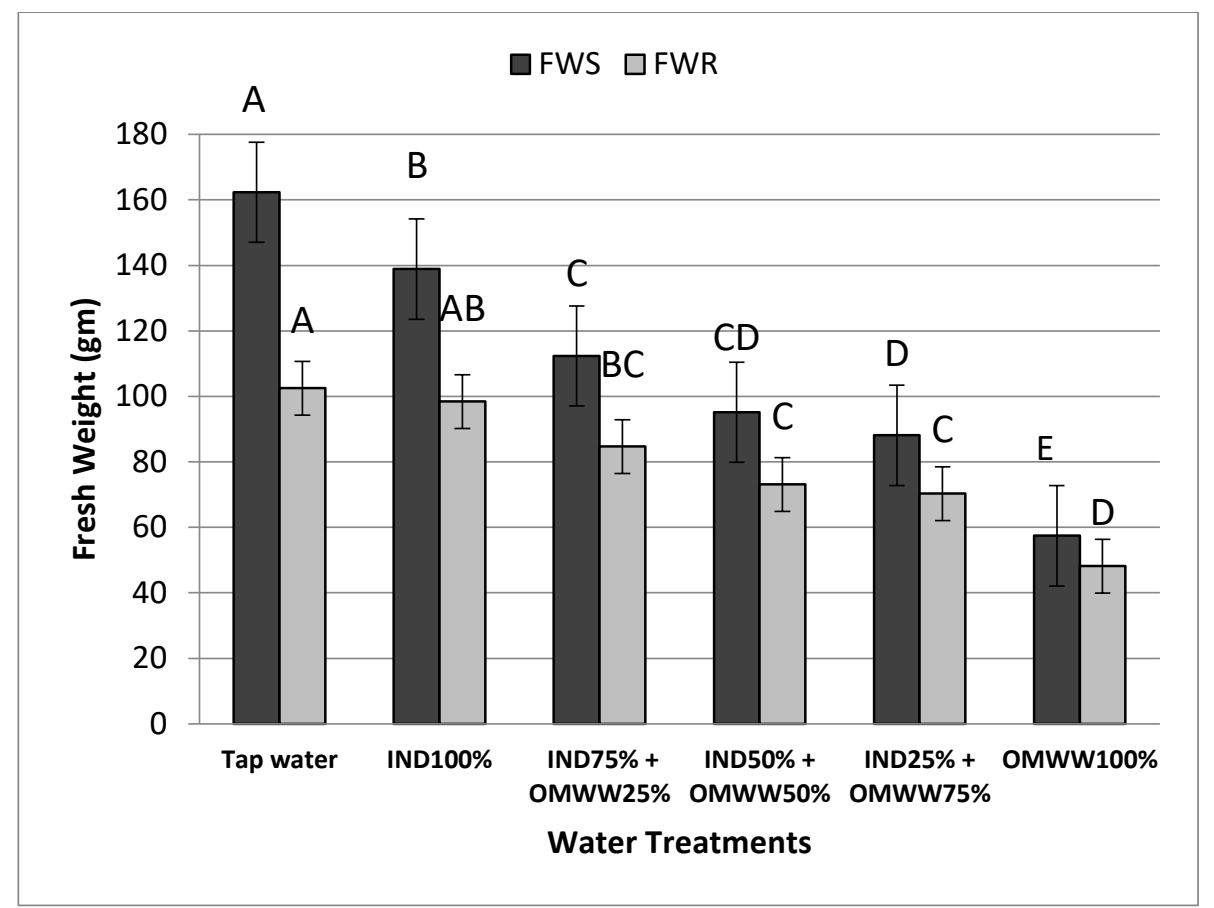

Fig 2. Fresh weight of shoot and weight root $(\mathrm{gm})$ of vetch seeds as affected by mixing different water qualities: tap water, IND $\mathrm{I}_{100 \%}$, $\mathrm{IND}_{75 \%}+\mathrm{OMWW}_{25 \%}, \mathrm{IND}_{50 \%}+\mathrm{OMWW}_{50 \%}, \mathrm{IND}_{25 \%}+\mathrm{OMWW}_{75 \%}, \mathrm{OMWW}_{100 \%}$.Values with the same letters are not significantly different based on least significant difference (LSD $=19$ and 18 for fresh weight shoot and dry root, respectively, $\mathrm{P}<0.05)$.

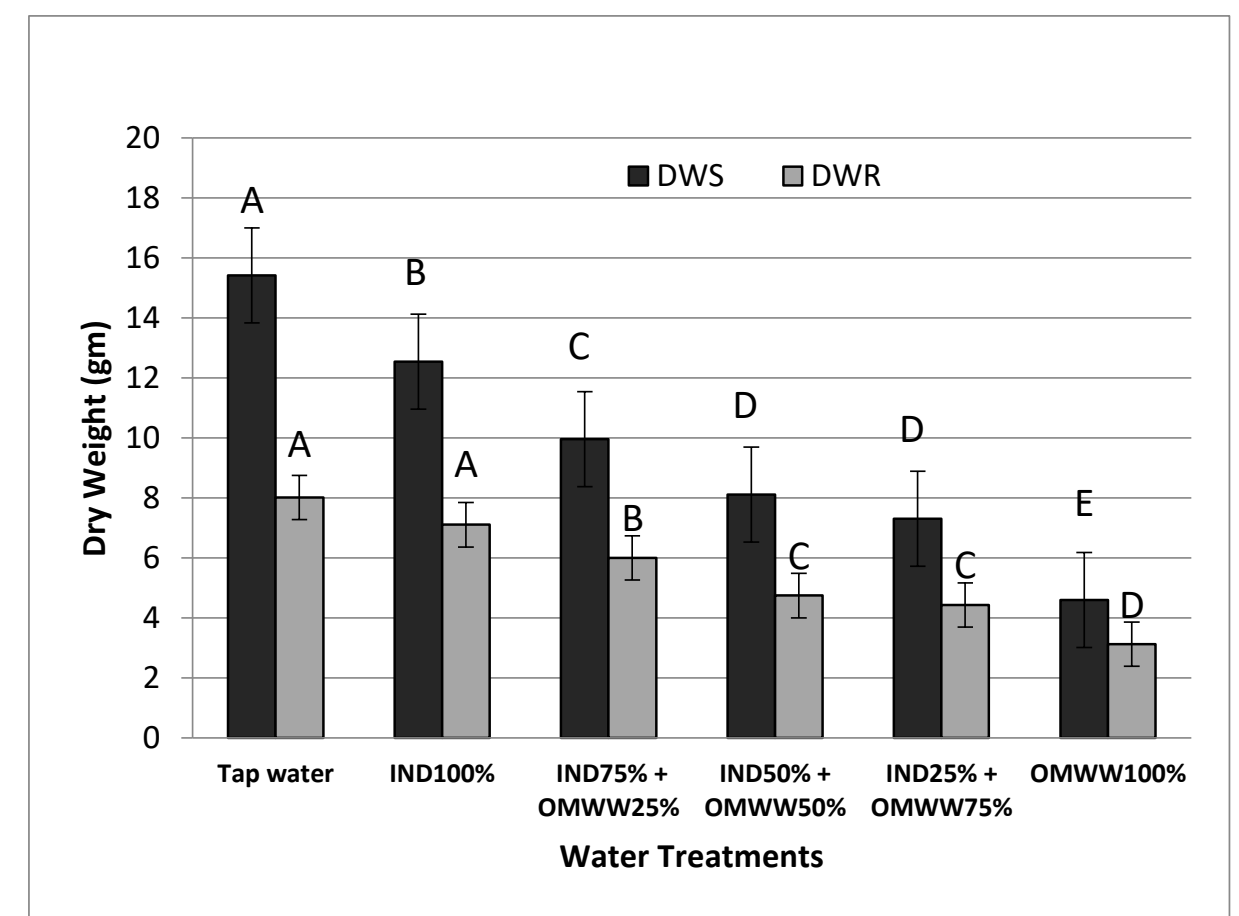

Fig 3. Dry weight shoot and dry weight root $(\mathrm{gm})$ of vetch seeds as affected by mixing different water qualities: tap water, IND ${ }_{100 \%}$, $\mathrm{IND}_{75 \%}+\mathrm{OMWW}_{25 \%}, \mathrm{IND}_{50 \%}+\mathrm{OMWW}_{50 \%}, \mathrm{IND}_{25 \%}+\mathrm{OMWW}_{75 \%}, \mathrm{OMWW}_{100 \%}$. Values with the same letters are not significantly different based on least significant difference (LSD $=1.72$ and 1.08 for dry weight shoot and dry root, respectively, $\mathrm{P}<0.05$ ). 


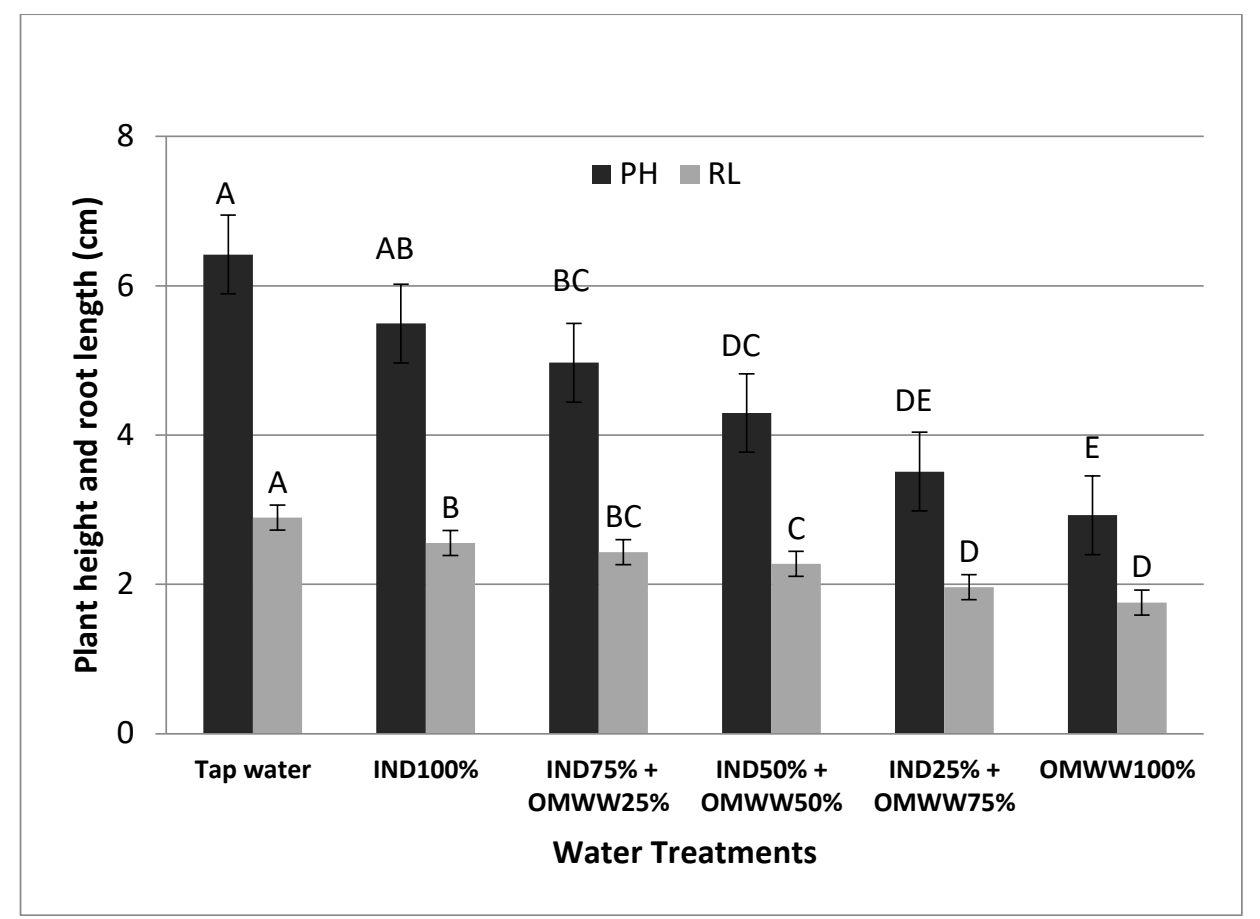

Fig 4. Plant height and root length $(\mathrm{cm})$ of vetch seeds affected by mixing different water qualities: tap water, $\mathrm{IND}_{100 \%}$, IND $\mathrm{IN}_{75}+$ $\mathrm{OMWW}_{25 \%}, \mathrm{IND}_{50 \%}+\mathrm{OMWW}_{50 \%}, \mathrm{IND}_{25 \%}+\mathrm{OMWW}_{75 \%}, \mathrm{OMWW}_{100 \%}$. Values with the same letters are not significantly different based on least significant difference ( $L S D=1.00$ and 0.28 for plant height and root length, respectively, at $\mathrm{P}<0.05$ ).

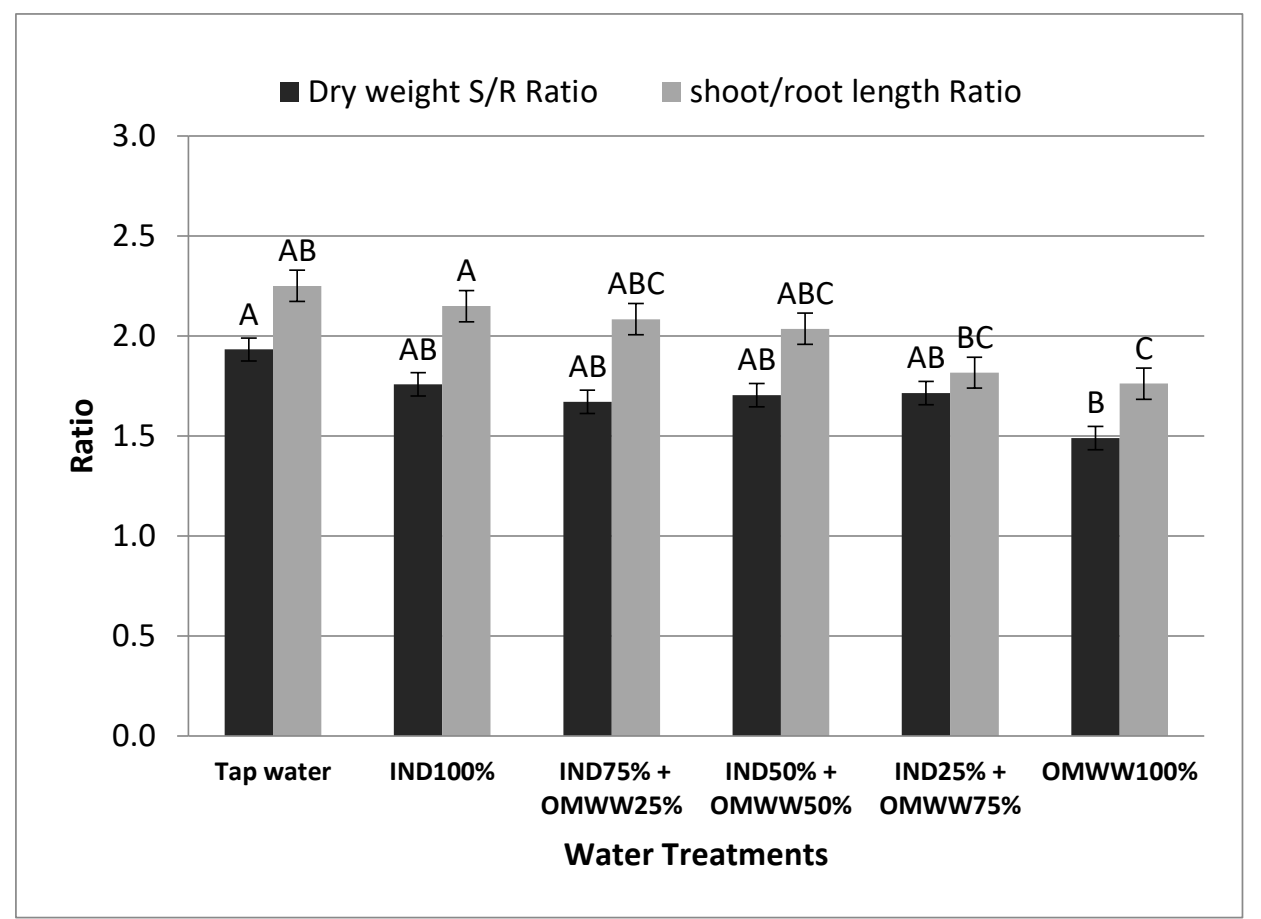

Fig 5. Dry weight ratio (shoot/root) and length ratio (shoot/root) of vetch germination as affected by mixing different water qualities:

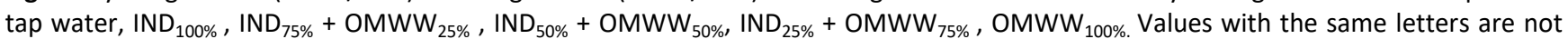
significantly different based on least significant difference (LSD $=0.45$ and 0.30 for dry weight Soot/Root ratio and length ratio of root /shoot, respectively, at $\mathrm{P}<0.05$ ). 


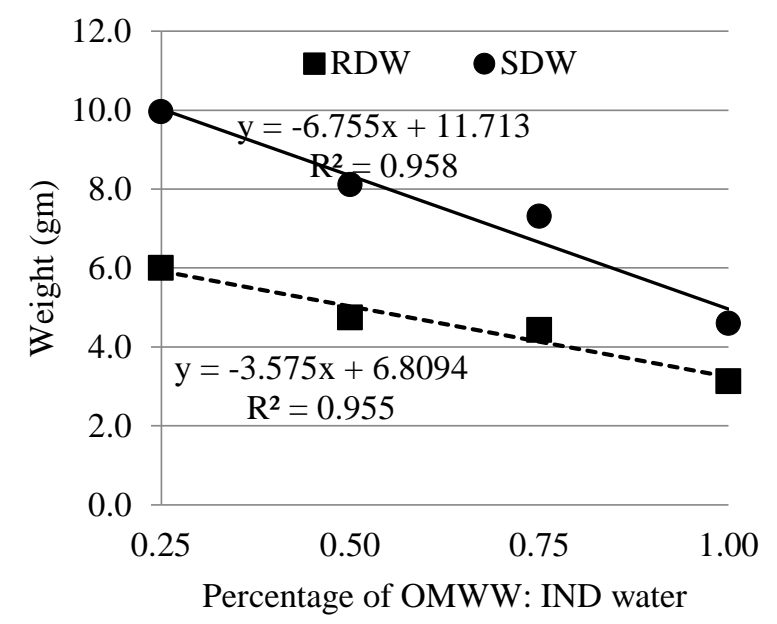

Fig 6. The relationship of the shoot and root dry weights as a function of the percentage of OMWW to the industrial water.

(DSW/RDW) was 1.76 for IND $_{100 \%}$ and the lowest was 1.49 for $\mathrm{OMWW}_{100 \%}$. The means of the DSW/RDW at different water mixing treatments were not different from each other. The highest SL/RL ratio (2.45) was obtained at $\mathrm{IND}_{100 \%}$ and the lowest (1.76) at $\mathrm{OMWW}_{100 \%}$. The means of $\mathrm{SL} / \mathrm{RL}$ ratio at $\mathrm{IND}_{50 \%}+\mathrm{OMWW}_{50 \%}, \mathrm{IND}_{25 \%}+\mathrm{OMWW}_{75 \%}$, and $\mathrm{OMWW}_{100 \%}$ were not different from each other. Our results are in accordance with the results of Tadros et al. (2012) and Mas'ad (2014) reported that non-treated IND water decreased the ratio (SL/RL).

\section{Effect of mixing ratio OMWW/IND on the shoot and root dry weight}

The relationships were observed between the shoot dry weights and increase of IND water and decrease of OMWW (Fig 6). These results reflect that the phenols concentration in OMWW increases when the germination parameters of vetch seeds decrease. This study found that when the industrial water increases in the mixture the germination parameters are increased as well. Similarly, Tadros et al. 2012 declared that the industrial water had a positive effect on germination of vetch seeds. Mas'ad (2014) reported that no significant differences were observed between dry weight of Vetch under raw and lime-treated OMWW compared to the significant decrease in Sorghum and Leucaena dry weight.

\section{Materials and Methods}

\section{Plant materials}

The vetch seeds (Vicia sativa L.) were obtained from farmer fields located close to Marrow Agricultural Research Station (about $80 \mathrm{~km}$ north of Amman, Jordan). The vetch seeds were grown in several areas, especially close to wastewater treatment plants for forage production.

\section{Experimental site and experimental design}

This study was conducted at the Jordan University Science and Technology, Faculty of agriculture in the laboratory of the Department of Plant Production in a controlled growth chamber $\left(20^{\circ} \mathrm{C}\right)$. The impact of different water qualities on the germination of vetch seeds as well as the early seedling stage was investigated under the control conditions. The water types of industrial and olive wastewater (OMWW) mixed together with different percentages. The water treatments consisted of T1 (pure IND $100 \%$ ), T2 (mix of IND $\left.\mathrm{OMWW}_{50 \%}\right), \mathrm{T} 4\left(\mathrm{IND}_{25 \%}+\mathrm{OMWW}_{75 \%}\right)$ and T5 (pure $\mathrm{OMWW}_{100 \%}$ ) and tap water (control). The experimental design used in this research was complete randomize design with three replications.

\section{Data collection}

Germination percentage, shoot length, root length, shoot fresh and dry weight, root fresh and dry weight, shoot to root length ratio (SL/RL) and shoot to root dry weight ratio (SDW/RDW) were determined according to Al-Tabbal (2017). The total number of seeds that germinated in each treatment after final count to the number of seeds that were planted was expressed as germination percentage. Shoot length and root length were taken daily after germination with ruler. Seedlings length that could be considered as a vigor test has potential to give information to the germination test and makes possible to estimate the potential of emergence of seedlings in the field. This character was measured by adding root length to shoot length. Shoot and root fresh weights were taken at the end of experiment after 21 days from the beginning of germination. Shoot and root dry weights were recorded after oven drying at $60^{\circ} \mathrm{C}$ for $48 \mathrm{hr}$. The ANOVA analysis was run for the data collected by using the SAS software version 9.0 (SAS, 2002). Means were tested by using Fisher's least significant differences (LSD) at probability level of 0.05 . 


\section{Industrial and olive mill wastewater collecting and analyzing}

The treated industrial was brought from the textile factory at Prince Hassan Industrial City that situated north of the Jordan University of Science and Technology (JUST) Campus. The olive wastewater was brought from olive mill wastewater that was located in Irbid (about $70 \mathrm{~km}$ north of Amman, Jordan) and was operated by centrifugation system. Samples were collected in plastic containers and maintained at $4{ }^{\circ} \mathrm{C}$. The industrial water treated physically and chemically only. The wastewater was treated physically, chemically, and biologically. The water quality parameters $(\mathrm{pH}, \mathrm{EC}, \mathrm{Na}, \mathrm{K}, \mathrm{Ca}$, $\mathrm{N} \%$, and phenols) analyzed in the laboratory of Wadi Al-Arab Waste Water Treatment Plant according to APHA (1995).

\section{Germination procedure}

Vicia sativa L. seeds were treated with mercuric chloride $(0.1 \%)$ to prevent surface fungal/bacterial contamination. Seeds were washed several times with water to remove the mercuric chloride particles. The germination test based on ISTA from 21 days was performed in wet autoclaved filter paper in sterile petri dishes (ISTA, 2003; Al-Tabbal and Ammary, 2014). Germination was distinct by radical emergence (Crowe et al., 2002).

\section{Conclusions}

We examined the effect of different percentages of mixing industrial water (IND) and olive mill wastewater (OMWW) on vetch germination during the early stages of germination. This study consisted of mixing IND with OMWW with different percentages as: tap water, $\mathrm{IND}_{100 \%}, \mathrm{IND}_{75 \%}+\mathrm{OMWW}_{25 \%}$, $\mathrm{IND}_{50 \%}+\mathrm{OMWW}_{50 \%}, \mathrm{IND}_{25 \%}+\mathrm{OMWW}_{75 \%}$, and $\mathrm{OMWW}_{100 \%}$. The increase in percentage of industrial water on OMWW caused a positive effect on germination characteristics mainly due to decrease in the acidity of water. On the contrary, seed germination characteristics were affected by increasing the percentage of OMWW due to the increase in the acidity and phenols concentrations. However, mixing the unconventional water such as IND and OMWW will decrease the stress on the fresh water, which is used for irrigation. The results of this research showed that the $I N D_{100 \%}, I N D_{75 \%}+O M W W=25, I N D_{50 \%}$ + OMWW $_{50 \%}$ were the best treatments as a results of the means of shoot dry weight, root dry weight, shoot length, and root length that were not different under $I N D_{50 \%}+\mathrm{OMWW}_{50 \%}$, $\mathrm{IND}_{25 \%}+\mathrm{OMWW}_{75 \%}$ treatments. Generally, the results of this study recommended that further research needs to be carried out in the field to study the effect of different percentages of water qualities on the seed vetch germination and seedling growth.

\section{Acknowledgement}

Authors would like to thank the Jordan University of Science and Technology (JUST) and Al-Balqa' Applied University (BAU) for supporting and funding this research.

\section{References}

Al-Tabbal JA, Ammary BY (2014) Effect of wastewater and grey water reuse on the germination and early growth of barley and onions. Global NEST J. 16 (5): 998-1005.

Al-Tabbal JA (2017) Germination and Physiological Traits to Ascertain the Ability of Hormonal Priming to Improve Salinity Tolerance in Sorghum bicolor. J Agron. 16: 138-146.

APHA (1995) Standard methods for the examination of water and wastewater. $18^{\text {th }}$ Edn. Am Pub Assoc Inc. Broadway, New York.

Aragues R, Puy J, Isidoro D (2004) Vegetative growth response of young olive trees (Oleaeuropaea L., cv. Arbequina) to soil salinity and waterlogging. Plant Soil. 258: 69-80.

Ayouba S, Al-Absi K, Al-Shdiefat S, Al-Majali D, Hijazean D (2014) Effect of olive mill wastewater land-spreading on soil properties, olive tree performance and oil quality. Sci Hortic. 175: 160-166.

Azbar NB (2009) A Review of Wate Management Options in Olive Oil Production. Izmir, Turkey: Ege University.

Azbar N, Bayram A, Filibeli A, Muezzinoglu A, Sengul F, Ozer A (2004) A review of waste management options in olive oil production. Crit Rev Environ Sci Technol. 34: 209-247.

Biggs TW, Jiang B (2009) Soil salinity and exchangeable cations in a wastewater irrigated area. Indian J Environ Health. 38: 887-896.

Chartzoulakis KS (2005) Salinity and olive: Growth, salt tolerance, photosynthesis and yield. Agric Water Manage. 78: 108-121.

Crowe AU, Plant AL, Kermode AR (2002) Effects of an industrial effluent on plant colonization and on the germination and post-germinative growth of seeds of terrestrial and aquatic plant species Environ Pollut. 117(1): 179-189.

DOS (2016) Department of Statistics. Population Estimates. Jordan.

Erel R, Dag A, Ben-Gal A, Schwartz A, Yermiyahu U (2008) Flowering and fruit set of olive trees in response to nitrogen, phosphorus, and potassium. J Am Soc Hortic Sci. 133: 639647.

ISTA (2003) International Seed Testing Association, ISTA Handbook on Seedling Evaluation: third edition.

JOPEA (2016) Jordan Olive Products Exporter Association. Jordan among world's top 10 producers of olive, olive oil.http://www.jordantimes.com/news/local/jordan-amongworld\%E2\%80\%99s-top-10-producers-olive-oliveoil\%E2\%80\%99.

Komilis DK (2005) The effect of olive mill wastewater on seed germination after various pretreatment techniques. J Environ Manage. 74 (4): 339-348.

Krogmeier MJ, Bremner M (1989) Effects of phenolic acids on seed germination and seedling growth in soil. Biol Fertil Soils. 8(2):116-122.

Mas'ad IS (2014) The Impact of Lime Treated Olive Mill Wastewater on Forest Trees and Forage Crops Growth, And its Potential Use By the Local Community in Northern of Jordan. Master thesis. Jordan University of science and technology. 
Mekki AD (2006) Olive wastewater as an ecological fertilizer. Agronomy for Sustainable Developemnt, Springer Verlag/EDP Sciences/INRA 21 (1): 61-67.

Mekki AD (2007) Polyphenols dynamics and phytotoxicity in a soil amended by olive mill wastewaters. J Environ Manage. 84 (2): 134-140.

MWI (2013) Jordan Water Sector: Facts and Figures. Amman, Jordan: Ministry of Water and Irrigation.

Palese AM, Pasquale V, Celano G, Figliuolo G, Masi S, Xiloyannis C (2009) Irrigation of olive groves in Southern Italy and treated municipal wastewater: effects on microbiological quality of soil and fruits. Agric Ecosyst Environ.129: 43-51.

Paraskeva CP (2007) Membrane filtration of olive mill wastewater (OMW) and OMW fractions' exploitation. Water Environ Res. 79: 421-429.

Reeve R (1990) A manual of integrated cereal/ livestock farming systems in Jordan. SAGRIC International. Jordan.

Rusan MA (2015) Evaluation of phytotoxicity effect of olive mill wastewater treated by different technologies on seed germination of barley (Hordeum vulgare L.). Environ Sci Pollut Res Int. 22 (12): 9127-9135.
SAS (2002) The SAS System for Windows version 9.0, SAS Institute, Cary, NC, USA.

Saoub A, Akash M (2012) Variations between two vetch landrace species in Jordan. J Food Agric Environ. 10(1):763767.

Segal E, Daga A, Ben-Gal A, Zipori I, Erel R, Suryano S, Yermiyahua $U$ (2011) Olive orchard irrigation and reclaimed wastewater: Agronomic and environmental considerations. Agric Ecosyst Environ. 40: 454-461.

Tadros MJ, Al-Mefleh NK, Mohawesh O (2012) Effect of irrigation water qualities on Leucaena leucocephala germination and early growth stage. Int J Environ Sci Technol. 9(2):281-286.

The forage information system. http://forages.oregonstate.edu/ (accessed 2April 2019)

USAID (2012) A review of water policies in Jordan and recommendations for strategic priorities.

Zenjari A, Nejmeddine A (2001) Impact of spreading olive mill wastewater on soil characteristics: Laboratory experiments. Agron Sustain Dev. 21: 749-755. 